\title{
PROBLEMS AND PROSPECTS OF THE INDONESIAN FOREIGN EXCHANGE SYSTEM*
}

\author{
Lawrence $\mathrm{J}$. White
}

In the late $1960^{\prime} \mathrm{s}$ the foreign sector of the Indonesian economy moved out of the thicket of direct quantitative controls and toward a system that relied on indirect pricing and market incentives. Today (December 1971), Indonesia is the largest (by population)' less developed country with an open, relatively uncontrolled foreign sector and a realistic exchange rate. A recent (August 22, 1971) ten per cent devaluation of the rupiah indicates that the Government of Indonesia is still committed to maintaining this open system and avoiding the dangers of widespread quantitative controls. Since Indonesia is almost unique in its commitment to an open system, and yet descriptions of the present day Indonesian economy are scarce, a discussion of this phenomenon may be worthwile.

This paper will try to describe and analyze the present Indonesian foreign exchange system. Section I will offer a brief description of the Indonesian economy as background. Section II will describe the foreign exchange system as it stands today. Section III will analyze the system and some of the problems that it faces. And Section IV will offer a foreign exchange strategy for the future.

\section{The Economy}

Genera1

Indonesia ranks noar the bottom of the less developed country income tables. In terms of GDP per capita, Indonesia is probably in the same range as India and Pakistan. The recent 1970 estimates put Indonesia's GDP at $\mathrm{Rp} 3,328$ billion. ${ }^{2}$ With an estimated population of 115 million, ${ }^{3}$ this works out to Rp 28,800 per capita. At the 1970

* A longer version of this paper was originally presented at the NBER conference on Exchange Control, Liberalization, and Economic Development, Feb ruary 26, 1972. Research support was provided by the United States Agency for International Development. I would like to thank David Cole, Jagdish Bhagwati, and Anne 0. Krueger for their helpful comments on earlier drafts.

1. The two larger less developed countries--Mainland China and India-both have controlled foreign sectors.

2. "Survery of Recent Developments," Bulletin of Indonesian Economic Studies (BIES), VII, No. 2 (July $1 \overline{971,}$ p. 3. This figure is GDP at factor cost.

3. Ibid., p. 17 . 
exchange rate of Rp 378 equals US $\$ 1$, this is $\$ 76$ per capita. It is unlikely that this figure, or the underlying average welfare of which it is supposed to be an index, is appreciably different from what it was in 1930. The years 1930-1950 encompassed the Great Depression (a poor period for raw materials prices, with especially severe effects on the sugar economies of East Java and Bali), the Second World War and heavy taxation by the Japanese occupation forces, and a four-year struggle for independence. These were not propitious times for economic growth. During the early 1950's, the economy prospered and made up some of the damage of the previous twenty years. But the subsequent departure of the Dutch, the spread of direct government controls to many sectors of the economy, and the increasing pace of inflation led to economic stagnation. The recent estimates of real GDP at constant market prices show a growth rate of 2.1 per cent between 1960 and 1966 , a rate that was just keeping up with population growth. ${ }^{4}$

As is true for most less developed countries, Indonesia's economy is primarily agricultural. Table 1 gives the average percentage GDP sectoral breakdown for the $1960-68$ period and the employment percentages ascertained in the 1961 census. The central island of Java is mostly a rice growing area with small, intensively cultivated plots. It is also heavily populated; the island has 65 per cent of the country's population on only 7 per cent of the land area. The other islands are more sparsely populated, and their inhabitants tend to grow mostly cash crops for export (rubber, copra, coffee, pepper, spices), though rice is also grown in some areas. Indonesia has been a rice importing country, and self-sufficiency in rice has been an important economic and political goal.

Table 1

GDP (Average 1960-68) and Employment (1961), by Sector (Percentages)

\begin{tabular}{lrc}
\hline & GDP & Employment \\
\hline Agriculture & 52.4 & 71.9 \\
Mining & 3.7 & 0.3 \\
Manufacturing & 8.5 & 5.7 \\
Construction & 1.8 & 1.8 \\
Electricity & 0.4 & 0.1 \\
Transport & 3.5 & 2.1 \\
Trade & 15.5 & 6.7 \\
Finance & 0.9 &.- \\
Dwellings & 2.0 & 9.5 \\
Public Administration & 4.9 & 1.9 \\
Services & $6.2)$ &.- \\
Other & 100.0 & 100.0 \\
& &
\end{tabular}

Source: Arndt and Ross, "The New National"; Alex Hunter, "Notes on Indonesian Population," in Bruce'Glassburner, ed., The Economy of Indonesia (Ithaca: Cornell University Press, 1971).

4. Bu1letin of Indonesian Economic Studies, VI, No. 2 (Ju1y 1970), pp. 142-147. 
A striking figure in Table 1 is the percentage of GDP originating in industry. Indonesia is relatively under-industrialized, even compared to its South and Southeast Asian neighbors. During the 1960's, Indonesia generated only 8.5 per cent of its GDP in the manufacturing sector (excluding mining). By contrast, the percentage of GDP originating in manufacturing during the same period in India was 15.6 per cent; in Pakistan, 11.0 per cerıt; in Malaysia, 9.4 per cent; in Thailand, 12.6 per cent; and in the Philippines, 18.5 per cent. ${ }^{5}$ Even in 1970, with much of Indonesia's industrial plant "rehabilitated" from the neglect and spare parts shortages of the Sukarno years, industrial output (value added) was only 10 per cent of GDP.

With industrial wages that are among the lowest in the world-industrial labor costs in 1971 are typically $R p$ 200-250 (US $\$ 0.55-$ $\$ 0.66)$ per worker per day--one would expect to find Indonesia with a comparative advantage in labor intensive manufacturing, 1ike textiles and assembly operations. But this potential comparative advantage has not yet materialized, for a number of reasons: weak infrastructures support (electricity, roads, rail, seat transport, message communications are al1 in poor shape); a general shortage of capital and entrepreneurial skills; a hostility to foreign capital investment and entrepreneurship during the Sukarno years; and fiscal, monetary and foreign exchange policies during the sukarno years that tended to discourage private capital formation and that did not generate enough efficient government capital formation. Within the manufacturing sector, about two-thirds of value-added in 1970 was generated in the comparatively simple activities of food, beverages, tobacco, and textiles, with hand weaving and hand batik-dying accounting for an appreciable part of this last area. ${ }^{6}$ Indonesia has not yet entered the lists of less developed countries trying to export manufactured products. In 1970, less than one-half per cent of Indonesian exports qualified as "manufactured."

The Stabilization Program ${ }^{7}$

A new political regime, led by General (later, President) Suharto, took power in early 1966, following the abortive coup of September 30 ,

5. H. W. Arndt and C. Ross, "The New National Income Estimates," Bulletin of Indonesian Economic Studies, VI, No. 3 (November 1970), Table 2, p. 49 .

6. Wilhelm Boucherie, "Some Preliminary Estimates Concerning the Present Structure of Industry" (Djakarta: Harvard Development Advisory Service, 1971), mimeograph.

7. For a further discussion of the inflation and the stabilization program, see H. W. Arndt, "Banking in Hyperinflation and Stabilization," in Bruce Glassburner, ed., The Economy of Indonesia (I thaca: Corne11 University Press, 1971); Bruce Glassburner, "Indonesian Economic Policy After Sukarno," in Glassburner, The Economy; and Gunnar Tomasson, "Indonesia: Economic Stabilization, 1966-69," Finance and Development, VII, No. 4 (December 1970). 
1965. The economy that the new regime inherited was in a shambles. Indonesia was in the throes of a hyper-inflation. The rate of inflation in 1965 was over 600 per cent per year. ${ }^{8}$ The banking system had disintegrated. The legal exchange rate was only 6 per cent of the black market rate. Appreciable amounts of exports were being smuggled out of the country, and capital, too, was likely being smuggled out. The Sukarno regime had run up huge foreign debts, mostly for military hardware and public monuments. Indonesia owed $\$ 2.4$ billion to foreign creditors, with little to show for it of a productive nature. The scheduled servicing of this debt called for $\$ 530$ million in 1966. Recorded exports in 1965 were only $\$ 634$ million.

Stopping inflation was a primary goal of the new regime. Measured on a January-to-January basis, inflation in 1966 was "down" to a rate of 420 per cent. In 1967 , the rate was down to 170 per cent. In 1968 , the rate fell further to 35 per cent. In 1969, prices rose 15 per cent, and in 1970 prices rose by only 4 per cent.

The proximate reasons for this halting of inflation are not hard to find: an end to government deficit spending, a more moderate expansion in the money supply, and a substantial inflow of resources from abroad. These phenomena are, of course, all related. In 1966 government expenditures were $\mathrm{Rp} 29.4$ billion, while tax and other receipts were only Rp 13 billion, or only 44 per cent of expenditures. The difference of $\mathrm{Rp} 16.4$ billion (this was 2 per cent of GDP) accounted for over 80 per cent of the expansion of the money supply in 1966 . But this 44 per cent receipts/expenditure ratio was an improvement from the preceding year, when the ratio had been 36 per cent. In 1967, the receipts picture improved considerably. Non-foreign-aid related receipts were $\mathrm{Rp} 60.2$ billion, or 85 per cent of routine budget expenditures. The counterpart funds from sales of foreign aid provided another Rp 24.7 billion, so that Rp 17.5 billion in development spending could take place. The overall deficit was only $\mathrm{Rp} 2.5$ billion, or less than 3 per cent of expenditures. By 1968 non-aid receipts were even with routine expenditures, and the overall budget was balanced. This was the first balanced budget Indonesia had achieved since 1951. As Table 2 indicates, by the 1969/70 fiscal year" a substantial surplus on "current account" had been obtained, and the government had become an important source of savings in the economy.

The ending of the government deficits was the product of both an increase in tax receipts and a decrease in real government spending, the latter occurring mostly on the capital budget. Many of the large public works and show piece projects of the Sukarno regime were stopped. As Table 2 indicates, "development" spending fell significantly in 1966 as a fraction of the government budget. Table 3 shows these effects yet more clearly. When corrected for inflation, routine government spending did not change appreciably, but real development spending fell in 1966. Also, it is likely that some of the Sukarno projects that were stopped were never accounted for in the official budget in the first place, so actual spending probably fell by more than the figures of Tables 2 and 3 indicate. At the same time, real tax receipts increased substantially. To some extent,

8. A maximum rate of 1500 per cent per year was reached between June 1965 and June 1966.

9. In 1969 , the government switched the fiscal year from one that was identical with the calendar year to one that begins on April 1. 
taxes were increased, especially in cases in which taxes and levies had been stated in absolute rupiahs, the value of which had been drastically reduced by the inflation. But also effective tax collection had disintegrated toward the end of the Sukarno years, and the new government, by bringing a greater measure of political stability, was simply able to collect existing taxes more effectively.

Table 2

Actual Government Revenues and Expenditures, 1965-1970/71 (bi11ions of Rupiahs)

\begin{tabular}{|c|c|c|c|c|c|c|}
\hline & 1965 & 1966 & 1967 & 1968 & $1969 / 70$ & $1970 / 71$ \\
\hline \multicolumn{7}{|l|}{ Revenues } \\
\hline $\begin{array}{l}\text { Taxes and other } \\
\text { domestic receipts }\end{array}$ & 0.9 & 13.1 & 60.2 & 149.7 & 234.7 & 344.6 \\
\hline Counterpart funds & -- & -- & 24.7 & 35.5 & 91.1 & 120.5 \\
\hline TOTAL & 0.9 & 13.1 & 84.9 & 185.3 & 334.8 & 465.1 \\
\hline \multicolumn{7}{|l|}{ Expenditures } \\
\hline Routine & 2.1 & 25.7 & 70.0 & 149.7 & 216.5 & 288.2 \\
\hline Development & 0.4 & 3.7 & 17.5 & 35.5 & 118.1 & 169.8 \\
\hline TOTAL & 2.5 & 29.4 & 87.6 & 185.3 & 334.7 & 457.9 \\
\hline Deficit or Surplus & -1.6 & -16.3 & -2.7 & - & -- & +7.2 \\
\hline
\end{tabular}

Source: Bank Indonesia, Indonesian Financial Statistics, October 1971 , pp. 68-71.

The preceding paragraphs overstate the case to some extent, since the budget figures exclude some government agencies which $r$ an at a loss and were directly subsidized by the central bank. Chief among these was the government rice procurement and price stabilization agency, BULOG. Further, the budget accounted for rice expenditures (for salary in kind) at a price paid by the treasury to BULOG that was below BULOG's costs, transferring deficits from the budget account to BULOG's account. Still, I believe that the trends shown in the tables are indicative of the true trends.

The inflation might have been brought under control even sooner than it was. The rate of price increase in the middle of $1967 \mathrm{had}$ definitely begun to slacken. But a poor dry season rice harvest at the end of 1967 sent the price of rice climbing again. The rice price in Djakarta, which had been roughly stable between January and August 1967, doubled between August and December 1967 and doubled 
again in the next month. Since rice has a 31 per cent weight in the price index, these rises were heavily reflected in the price index. Further, "sympathy" movements in other prices followed with a short 1ag. Since most prices and wages tend to be keyed to the price of rice, these "sympathy" rises were to be expected.

Table 3

Price Corrected Government Revenues and Expenditures, 1965-1970/71 (in September 1966 Rupiahs)

\begin{tabular}{lrrrrrr}
\hline & 1965 & 1966 & 1967 & 1968 & $1969 / 70$ & $1970 / 71$ \\
\hline $\begin{array}{l}\text { Price Index } \\
\text { (September 1966=1.00) }\end{array}$ & 0.07 & 0.76 & 2.06 & 4.63 & 5.63 & 6.26 \\
$\begin{array}{l}\text { Revenues } \\
\text { Taxes and other } \\
\text { domestic receipts }\end{array}$ & 12.6 & 17.2 & 29.2 & 32.3 & 43.3 & 55.0 \\
Counterpart funds & -- &.- & 12.0 & 7.7 & 16.2 & 19.2 \\
$\quad$ TOTAL & 12.6 & 17.2 & 41.3 & 40.0 & 59.5 & 74.3 \\
$\begin{array}{l}\text { Expenditures } \\
\text { Routine }\end{array}$ & 30.0 & 33.8 & 34.0 & 32.3 & 538.5 & 46.0 \\
Development & 5.7 & 4.9 & 8.5 & 7.7 & 21.0 & 27.1 \\
$\quad$ TOTAL & 35.7 & 38.8 & 42.5 & 40.0 & 59.0 & 73.1 \\
\hline
\end{tabular}

Source: Bank Indonesia, Indonesian Financial Statistics, October 1971, pp. $68-71$.

Large rice imports in early 1968, mostly from PL 480, stabilized the rice price and lowered it somewhat, but the catching up of other prices continued to push the overall index up. Only by the first quarter of 1969 did other prices reach the same rough parity with rice that had existed in late 1966 and early 1967. In the absence of major structural changes, which are unlikely to have occurred over this period, we would expect this rough parity to re-assert itself. Thus, only by the first quarter of 1969 had the full effects of the poor harvest of the 1967 dry season been worked out. With better luck, the inflation might have ended a year earlier.

The inflow of external resources was also important to the halting of inflation. In 1966, the net inflow on government account (aid less debt repayment) was $\$ 96$ million and private capital inflow was $\$ 50$ million. In 1967 , these figures jumped to $\$ 219$ miliion and $\$ 100$ million, respectively. As seen in $\mathrm{Table} 4$, net official inflows continued to expand while prive inflows fell and then recovered in 1970. (The recent private capital inflow figures probably underestimate considerably the amounts of capital flowing in to finance activities like oil exploration.) These inflows made more goods 
available to the economy, and to some extent they also transferred rupiahs from the private sector to the government. Between 75 per cent and 90 per cent of the annual gross aid inflows were in the form of program aid, much of which the government sold off to the private sector. The government then used these counterpart funds as it did other fiscal receipts. This should not be confused with inflationary finance. By selling the aid, the government gained the claims over domestic resources that the buyers of the aid goods had formerly possessed. The counterpart rupiahs were thus a noninflationary claim on domestic resources in the same way that tax rupiahs were a non-inflationary claim.

Table 4

Capital Flows, 1966-1970 (millions of dollars)

\begin{tabular}{lrrrrr}
\hline & 1966 & 1967 & 1968 & 1969 & 1970 \\
\hline Program Aid & $a$ & 195 & 246 & 249 & 284 \\
Project Aid & $a$ & 69 & 20 & 69 & 110 \\
Other Aid (net) & $a$ & 9 & 32 & 7 & -28 \\
$\quad$ TOTAL & 96 & 273 & 298 & 325 & 366 \\
Debt Repayment & $a$ & -54 & -75 & -40 & -66 \\
Private Capital (net) & 50 & 100 & 33 & 55 & 109 \\
Net Capital Flow & 146 & 319 & 256 & 340 & 409 \\
\hline
\end{tabular}

a. The $\$ 96$ million in 1966 represents gross aid less debt repayment.

Source: Bank Indonesia, Indonesian Financial Statistics, October 1971, pp. 128-129, 140 .

Hand in hand with efforts to increase the inflow of external resources were efforts to re-schedule the debt obligations of the Sukarno regime. The original obligations, requiring an immediate payment of $\$ 530 \mathrm{mi} 11$ ion in $1966, \$ 270 \mathrm{milli}$ on and $\$ 275 \mathrm{million}$ in 1967 and 1968 , and further annual payments into the $1980^{\prime} \mathrm{s}$, would have had a crushing effect on the economy. A moratorium on Sukarno debt repayments was declared, and negotiations with the creditor countries followed. (Repayments were maintained however, on short-term obligations incurred after 1965.) Finally, in 1970, agreement on rescheduling was achieved with Indonesia's Western creditors, and the following year a similar agreement with its Socialist creditors was reached. Since debt repayments would have had the opposite effect of aid inflows on the economy, 10 the moratorium and rescheduling greatly facilitated the government's efforts to close its receipts expenditures gap.

10. To the extent that aid was tied and worth less than free foreign exchange, debt repayments would have been yet more costly for the economy and not just symmetrical with aid. 
Finally, with government deficits eliminated, the major source of money supply expansion had been eliminated. These actions were supported by a general high interest rate policy. In October 1966, interest rates were hiked to 6-9 per cent per month from their previous nominal rate of 9 per cent per annum. The government announced as a goal that 90 per cent of all new credits should be for the financing of new production and exports. Importers were required to prepay 100 per cent of the value of their imports plus 50 per cent of the duties and were limited in their ability to borrow for this purpose.

By April 1967 these measures had had a large disinflationary effect, and the business community had begun to object. In that month, interest rates were lowered to 4-7 per cent per month, the import prepayment was reduced to 25 per cent of import value, and the prepayment of the import duties was abolished. (Subsequently, the 100 per cent import prepayment was restored, and duty prepayments were re-imposed sporadically.) Since that time, interest rates on loans have drifted downward until, in mid-1971 they stood at a $1-4$ per cent range per month.

Further, interest rates were made attractive on the saving side. In October 1968 the government instituted a program of time deposits paying 1-1/2 per cent per month on one month deposits up to 6 per cent per month on one year deposits, tax free, no questions asked. With the inflation largely over by this time, the latter rate soon became too high and was lowered to 5 per cent in March 1969 and lowered again a number of times in 1969. In mid-1971, the time deposit rates were 1 per cent per month on one month deposits, 1-1/2 per cent per month on three month deposits, 1-3/4 per cent per month on six month deposits, and 2 per cent per month on one year deposits.

The response to these interest rates was strong. In December 1968 , three months after the beginning of the program, $\mathrm{Rp} 4.4 \mathrm{bili}$ in deposits were in the program. Six months later, the figure was $\mathrm{Rp} 24.5$ billion. In December 1969, they had grown Rp 33.6. By mid1971 this figure had grown to Rp 73.7 billion.

Despite the high interest rate programs described above, the money supply continued to expand but at a slackened pace from the pre1966 period. And, as price increases slackened for all of the reasons discussed above, transactions velocity declined and the public's willingness to hold cash balances increased. Between December 1965 and March 1971, the real money holdings of the economy increased by over four-fold.

Why Did Stabilization Succeed?

The stabilization program that has been described was essentially quite an orthodox one. That it worked is really no surprise. That it was allowed to work is another question. What was it about the social-economic-political structure of Indonesia that allowed this stablization program to work? This question has special interest, since many similar stabilization packages have repeatedly failed to halt much more moderate inflations in Latin America.

The sheer pace of the inflation probably made it easier to bring about a stabilization program. Though, undoubtedly, some groups 
gained relatively and some groups lost through the inflation, price increases of 600 per cent a year must have created great uncertainities for al1. The price level doubled between March and September 1965; it sextupled between September and the following March. With this kind of pace and acceleration, even the gainers might have concluded that they would be better off with less inflation and less uncertainty. Further, by late 1965, the inflation had fed on itself and velocity had increased substantia1ly. For example, between December 1964 and December 1965, the money supply increased four-fold but prices increased six-fold. The political uncertainties of the last three months of 1965 surely accelerated the velocity. But, with the assumption to power in 1966 of a new government that at least seemed to promise political stability, velocity was likely to decrease, and some slackening of the inflation rate was likely to occur.

But these arguments only explain why a stabilization program might be allowed to begin and gain initial successes; they do not explain why the gainers from inflation would allow a stabilization program to continue after the inflation had slackened but not ceased. And, indeed, the April 1967 lowering of interest rates was in response to the complaints of a business community that was being hurt by the deflationary effects of the stabilization. But even after April, interest rates of 4-7 per cent represented hefty borrowing charges and, except for the few months at the time of the bad rice harvest, represented positive real rates of interest. The stabilization program was not junked in April 1967, and we must find further reasons why it was allowed to succeed.

First, the new government that took power in 1966 was certainly less anti-Western in its political outlook than the Sukarno regime had been. The stabilization program coincided with the views of the Western aid donors as to how a basis for economic growth in the Indonesian economy should be established. Had this aid not been forthcoming, it is most unlikely that the stabilization program could have been carried out as successfully and as quickly as it was.

A second reason for the success of the stabilization program is that Indonesia is not very urbanized. The 1961 census indicated that 15 per cent of the population lived in urban areas. ${ }^{11}$ Though this percentage had surely growth by the mid and late 1960 's, it was still considerably below the 40-70 per cent range usually found in Latin America. Thus, the urban constituency that might have benefited from inflation, through employment on deficit-financed urban monuments and public works and through the purchase of subsidized commodities, was simply not very big.

Third, Indonesia is not very industrialized. The manufacturing sectors are frequently hit hard in Latin American deflations, and the workers in the manufacturing sectors are frequently vocal in their opposition to the effects of deflation. But, as noted above, the manufacturing sector is small in Indonesia. Manufacturing employment was only 5.7 per cent of total employment in 1961 , and that percentage probably did not grow during the $1960^{\prime} \mathrm{s}$. Further, much of this manufacturing was in comparatively simple, basic items, the demand for which was likely to be income inelastic. Also, manufacturing had not benefited appreciably during the inflation. The available GNP figures

11. Alex Hunter, "Notes on Indonesian Population," in Glassburner, The Economy. 
indicate that real income originating in the manufacturing sector between 1961 and 1965 did not expand. And for some large-scale operations, like textiles and automobile assembly plants, output surely declined as the economy became more chaotic and raw materials and spare parts became more difficult to obtain.

Fourth, the urban and industrial population has not been strongly organized. Labor unions and associations of white collar and government employees were never economically strong because of general surplus labor conditions, but they were politically powerful before 1965 . They were estimated to have within their ranks $20-25$ per cent of the wage and salary workers in industry and government service. ${ }^{12}$ But since 1965 , their political power has been broken. There has simply been no one to lead the urban groups that may have been the losers from stabilization. In one late instance with which this author is personally familiar, the government in January 1970 ended the subsidy on kerosene and doubled its price. This is the sole cooking fuel for most Indonesians and an important item in their consumption; as a consequence of the price increase, the cost of living index jumped by 3.3 per cent. Yet the comparatively moderate and ineffectual street demonstrations that followed the price announcement were led by students. There was no other leadership group around to lead them.

As a summary and extension to these arguments, one might say that the September 30 coup failure and its aftermath changed the nature of Indonesian politics. A new, explicitly military government came to power. Those who had benefited from the Sukarno politics were no longer in power, and their organizations were disbanded or rendered ineffectual. The political channels that had been built up during the previous fifteen years were in ruins, and in this vacuum the new government was able to carry out its stabilization program along orthodox or classical "1iberal" lines in order to provide the foundation for a development program along liberal lines. The political and financial encouragement of the United States, Western Europe, and the IMF, and the World Bank greatly facilitated this program.

As a final note to this section, it is worth mentioning that recent GDP estimates for 1970 indicate that real GDP at market prices grew by about 23 per cent between 1966 and $1970 .{ }^{13}$ This is not an unimpressive rate for an economy that was simultaneously going through a deflationary stabilization program.

\section{The Present Foreign Exchange System}

Genera1

Indonesia currently operates what is basically an open foreign exchange system. This is a relatively recent phenomenon. The foreign

12. E. D. Hawkins, "Labor in Developing Countries: Indonesia," in Glassburner, The Economy.

13. See Bulletin of Indonesian Economic Studies, VI, No. 2 (July 1970), pp. 142-147, and Bulletin of Indonesian Economic Studies, VII, No. 2 (July 1971), p. 3. 
exchange history of the Sukarno regime was largely one of overvaluation (despite multiple exchange rates), required surrender of export proceeds, and quantitative import and capital controls, with short periods of liberalization always followed by a re-application of controls when an import surge and/or capital flight threatened the balance of payments. ${ }^{14}$

In early 1966, with the inflation at its height, the government decided to let the system of multiple exchange rates float mainly in response to market forces, so that exporter returns would keep pace with the rising prices and export smuggling would be discouraged. Over the next three years, the exchange rates floated upwards, quantitative controls over imports and capital flows were progressively unwound, export taxes were reduced, and the multiple exchange rates were consolidated. ${ }^{15}$ These actions were consistent with the general "de-control" that the Indonesian economy was experiencing and with the government's desire to encourage exports and discourage export smuggling. By April 1970 the exchange rate was consolidated to one basic rate, and this rate was stabilized at $R p 378=\$ 1.16$ Final1y, in August 1971, as pressure developed on Indonesia's balance of payment and in the wake of the U.S. float, Indonesia devalued by 10 per cent.

The nominal exchange rate currently is $\mathrm{Rp} 415=\mathrm{US} \$ 1$, and a11 transactions take place at that rate. The exchange rate is not officially pegged, but since late 1968 the policy of the Bank Indonesia has been to stabilize the exchange rate at a particular level (which has changed twice) through purchases and sales in the foreign exchange market.

Since there is no exchange control, Indonesians and foreigners alike are free to buy, sell, and hold foreign exchange. Though exporters are required to turn in their foreign exchange proceeds to the Central Bank upon receipt, this is mainly for tax recording purposes. The exporters are free to buy back the foreign exchange, paying the small difference between the Bank's buying and selling rates. In essence, the provision adds a minor tax (roughly $1 / 2$ per cent) to export transactions. Foreign investment is welcomed, though all foreign investment schemes must be approved by a government agency, the Foreign Investment Board.

14. W. M. Cordon and J. A. C. Mackie, "The Development of the Indonesian Exchange Rate System," Malaysian Economic Review, VII, No. 1 (Apri1 1962); S. Kanesa-Thasan, "Mu1tiple Exchange Rates: The Indonesian Experience," International Monetary Fund Staff Papers, XIII, No. 2 (July 1966).

15. More details can be gained from the "Survey of Recent Developments," contained in every issue of the Bulletin of Indonesian Economic Studies. See also Bruce Glassburner, "Pricing of Foreign Exchange in Indonesia, 1966-67," Economic Development and Cultura1 Change, XVIII, No. 2 (January 1970), and William C. Hollinger, "The Foreign Exchange Rate as a Policy Instrument: The Indonesian Case, 1966$70, "$ paper presented to the Dubrovnik Conference of the Harvard Development Advisory Service (June 197), mimeograph.

16. The dual exchange rates preceding April 1970 had been stabilized earlier. The lower (BE) rate had been stabilized at $\mathrm{Rp} 326=\$ 1$ in October 1968 and the higher (DP) rate had been stabilized at $\mathrm{Rp} 378=\$ 1$ in March 1969 . 


\section{Exports}

Most exports are subject to a 10 per cent export tax, bringing the effective exchange rate for exports down to Rp 374 . Manufactured exports and handicrafts are exempt from the 10 per cent tax, but these items accounted for less than 1 per cent of Indonesian exports in 1970. (Semi-processing of raw materials like rubber or copra does not count as manufacturing.) Also, petroleum and petroleum products are exempt from the tax; these exports are the special concern of the state-owned oil company, and special transfers from the company are allocated to the central treasury. In the 1970-71 budget year, export taxes brought in Rp 30.4 billion, or 9 per cent of the central government's tax receipts.

Many raw materials which leave a province (there are twenty-six provinces) have to pay an absolute levy, the cess, whether the raw materials are destined for export or for other provinces, and copra, coffee, and pepper are also subject to rehabilitation fund levies. ${ }^{1}$ In the past, the sum of these levies has gotten as high as 15 per cent (on copra), though it was only 1 per cent on rubber. Since most rubber is exported, the rubber cess was effectively an additional export tax. For most other materials, like copra, coffee, and spices, there are substantial domestic demands, and the materials tend to move from one province to another, so there is no direct discrimination against exports. As part of the August 1971 devaluation package, the rubber cess was removed, the copra and coffee cesses were halved, and the rehabilitation fund levies were substantially reduced. The effective tax from the cess and rehabilitation funds is now 0 per cent on rubber, 6 per cent on copra, 5 per cent on coffee, and 1.5-2.0 per cent on pepper.

Table 5 shows the approximate levels of the different Indonesian exports for calender year 1970. About 60 per cent of the total is accounted for by the two categories: petroleum and rubber. The addition of three more categories--lumber, coffee, and tin--brings the percentage to over 80 per cent. This is a high level of concentration, by any definition. The remaining 20 per cent is composed of a scattering of other raw materials. The only manufactured export large enough to rate a separate listing in government export statis tics is $\$ 2.3$ million worth of handicrafts.

Imports

Most imports are subject only to the restraints of import duties. The Indonesian import duty schedule is the usual cascaded hodgepodge found in most developing and developed countries. Capital goods bear duties of $0-30$ per cent, raw materials pay between 0 and 70 per cent,

17. The cess and rehabilitation fund levies are supposed to be spent on infrastructure relating to the taxed exports (e.g., roads, warehouses, shipping facilities, research). There has been a great deal of dissatisfaction on the part of producers and exporters, who have not perceived many new facilities being generated by these taxes. This may have been one of the contributing factors in the decision to reduce them in August 1971. 
Table 5

\begin{tabular}{lr} 
Exports, & (millions of dollars) \\
Petroleum & \\
Rubber & 434 \\
Lumber & 270 \\
Coffee & 125 \\
Tin & 71 \\
Palm Oil & 62 \\
Copra & 38 \\
Tea & 30 \\
Tobacco & 19 \\
Tapioca & 12 \\
Copra Cakes & 9 \\
Hides Kalm Kernels & 7 \\
Palm & 6 \\
Pepper & 5 \\
Other & 82 \\
& TOTAL \\
\hline
\end{tabular}

a. Because the check price values were appreciably below the true export values for the first three months of 1970, the actual export values must necessarily be guesses.

Sources: Bank Indonesia, Indonesia Financial Statistics, October 1971, pp. $130-133$.

semi-finished products bear duties of 30-120 per cent, and consumer goods pay between 30 per cent and 300 per cent. A few basic foodstuffs, like rice and wheat flour, have a zero duty. On an unweighted basis, import duties average 55 per cent. Weighted by total imports for calendar year 1970, import duties averaged 14 per cent; if the major duty-free items of rice, wheat flour, fertilizer and oil companyrelated imports are excluded from the total, import duties averaged 18 per cent. Government agencies are expected to pay duties on their imports, just like other importers. In addition to import duties, sales taxes are levied on imports, at rates of $0,5,10,20$, or 50 per cent. A separate sales tax schedule applies to domestically produced goods. Though the rates on domestic and imported items are frequently consistent, there are differences and even cases in which the domesitic product is taxed more heavily than the import. In the 1970/71 budget, import duties brought in Rp 70.7 billion and the import sales tax brought in another $\mathrm{Rp} \mathrm{22.1.} \mathrm{Together,} \mathrm{they} \mathrm{accounted} \mathrm{for} 27$ per cent of tax receipts. If export taxes are added, all taxes on trade accounted for 36 per cent of budgetary tax receipts.

Table 6 provides a rough breakdown of imports in 1970 as provided by Bank Indonesia. ${ }^{18}$ Two items from the table are worth noting. First,

18. Total imports are listed in the balance of payments as $\$ 1,138$ million on the FOB basis. An 11 per cent factor is usually applied to bring imports up to a CIF basis. This yields $\$ 1,263$ miliion. Bank Indonesia gives a break-down of $\$ 1,132.7$ million on a CIF basis, excluding imports for the oil companies. These last were $\$ 92$ million on an FOB basis of $\$ 102$ million CIF. This leaves $\$ 28$ million which was unclassified. 
rice and wheat flour imports totaled $\$ 170.3$ million, or 13 per cent of the total import bill. However, most of these foodstuffs were provided through foreign aid on free or very easy (e.g., PL480) terms. Second, colored and uncolored textile imports came to $\$ 36.9 \mathrm{million}$; also, a sizable fraction of the unclassified imports were probably textiles. This sizable level of textile imports into a country with industrial wages that are among the lowest in the world is a good indicator of the low level of industrialization of the country.

Tab1e 6

Imports, 1970 (millions of dollars, C.I.F.)

Rice

Wheat flour

Textiles

Cambrics and sheeting

Motor cars

Other consumer goods

Total consumer goods

Cloves

Chemicals

Chemical products and preparations

Paint materials

Fertilizer

Paper

Weaving yarns

Cement

Iron and steel products

other raw materials

Total raw materials

Iron and steel pipes

Machinery and engines

Buses and trucks

Other capital goods

Total capital goods

Imports for 0il Companies

Unclassified (estimated)

Total Imports
$\$ 111.2$

59.1

32.7

4.5

14.9

145.4

$\$ 367.8$

20.7

53.6

11.5

16.4

22.5

23.5

35.6

14.6

40.9

146.5

385.4

9.9

39.5

52.0

278.1

102.0

28.0

$\$ 1,262.7$

Source: Bank Indonesia, Indonesia Financial Statistics, October 1971, pp. 128-129, 136-137.

A complete study of the allocative effects of Indonesia's import duty structure has not yet been made, but the structure appears to yield positive and substantial effective protection for many import substitution activities (i.e., the net effect of duties on outputs and on inputs is to yield a positive and large increase in the value added of these activities). The structure of imports and the low level of industrialization indicate that entrepreneurs are only just beginning to take advantage of this protection. 
The Exceptions

There are some exceptions to the picture of an open economy described above. A handful of exports are prohibited: low quality rubber from some parts of Indonesia (Kalimantan); gold and silver and their ores; iron, brass, and copper scrap; and cultural antiquities. only the rubber provision is economically important. It is designed to improve Indonesia's image as a high quality exporter and is also designed to encourage domestic remiliing and crumb rubber operations in particular areas. Rubber remillers and crumb rubber factory owners in other areas (e.g., Sumatra) have been urging the government to extend the ban to their areas.

Second, copra exports from Sulawesi and the Malukus (these areas account for 90 per cent of Indonesia's copra exports) are under the direction of the Ministry of Trade, through its Copra Management Board. Copra exports in this area have had a history of informal local taxes. The consequences were a reduction in financial yields to small-holder copra farmers, neglect of copra growing areas and the absence of replanting, and a decline in copra exports. In efforts to change this situation, the Copra Management Board was set up in August 1969. It licenses who can engage in copra export and inter-island trade, how much they may ship, where they must buy, and where they must sel1. At the same time, the Board has made strenuous and largely successful efforts to eliminate the informal local taxes and is trying to ensure that formal local taxes (e.g., the cess and a special Board levy) do get spent on infrastructure related to copra. Returns to copra farmers do seem to have improved, and the buying and selling restrictions have not proved very onerous so far. Nevertheless, there does seem to be room for a less restrictive system that would still yield benefits for copra farmers.

There are more exceptions on the import side, and they are more important. First, there are five commodities tne import of which has been reserved exclusive1y to government agencies. These are rice, wheat flour, cotton fertilizer, and sugar. These five commodities accounted for roughly $18-20$ per cent of total imports in 1970. Some reasons can be offered for the government's desire to retain exclusive import rights to the commodities. Rice and wheat flour imports are crucial to the government's program of rice price supports, price stabilization, and long-term self-sufficiency. The government believes that it has better information and is better equipped on the logistics of the program than are private traders, and the government considers its program so crucial that it is not willing to leave these imports to the vagaries of the private sector. Also, these imports are largely bought through aid money, and by retaining control over these imports the government can minimize the hard foreign exchange that is spent on them. Though the minimization could also be achieved by differential pricing of the aid foreign exchange, donors frown on such practices (e.g., the U.S. government's requirement that PL 480 imports be sold at the highest prevailing rate of exchange). Cotton is imported exclusively under PL480, and the government has considered it easier, for the above reason, to retain exclusive control. The Ministry of Trade has exclusive import rights for fertilizer, because of an incident a few years ago in which an unauthorized individual in the government ordered from a foreign producer a large amount of fertilizer at an unfavorable price. The government felt itself obligated to honor the commitment, but to prevent the recurrence of the incident it restricted fertilizer imports to the Ministry of Trade. There is no 
good reason for the sugar restriction, but Indonesia is not alone in intervening in the sugar market. There seem to be few countries, developed and less developed alike, that do not actively intervene in the sugar market.

Second, a number of imports are banned entirely. Table 7 is ts these items. Until August 1970, only the first five items were banned. In the last few months of 1970 , in response to protectionist pressures from local manufacturers, the government put the remaining items on the 1ist. Not too surprisingly, all but three of the items are consumer goods. At the moment, the economic effect of the bans is probably small, and there has been no inclination on the part of the government to expand the 1ist since November 1970. Nevertheless, the precedent may be an unhappy one.

Table 7

Banned Imports, as of July 1971

Batiks and batik-motif cloth

Printed matter in the Indonesian language

Vehicle tires of certain sizes

Fully assembled commercial vehicles (into Java and Sumatra)

Used bottles

Dry cell batteries of certain sizes

Striped cotton cloth

Galvanized iron sheets

Ungalvanized iron sheets

Built-up radios and TV's

Semi-knocked-down radios and TV's

Canned condensed milk

Lamps and bulbs of certain sizes

Built-up motorcycles

Mosquito incense

Source: Ministry of Trade

Analysis and Problems

This section will draw on the discussion of the previous three sections and will analyze the effects that the foreign exchange system has had on the Indonesian economy and the problems that it has created. A number of themes will be discussed: the question of why quantitative controls have largely been avoided; the nature of the operation of the system; export incentives; pricing foreign aid; and foreign investment problems.

The Lack of Quantitative Restrictions

There is no single reason why Indonesia has largely avoided quantitative restrictions since 1965. Rather, a number of mutually reinforcing arguments have led Indonesian policy-makers to these policies. 
First, the aid donors were favorably inclined toward an open foreign exchange system. It is certainly debatable as to whether the aid flows and commitments would have been forthcoming in the same magnitudes if the direct controls of the pre-1965 era had continued.

Second, most of the new policy makers were ideologically favorable toward policies involving less direct controls. Many of the "technocrats," as the new ministers and their advisers came to be called, had been trained in the United States in economics during the 1950's and early 1960 's.19 These were men who were sympathetic toward markets and the results that markets yielded. Their orientation was certainly not complete laissez faire, but they were much more inclined to avoid direct controls and to intervene through the market rather than bypass the market.

Third, the widespread breakdown and clear failure of the Sukarno regime's direct controls was a clear and powerful demonstration of the potential difficulties of a system of quantitative restrictions. The import licensing cum overvalued exchange rate had generated widespread export and import smuggling, exacerbated corruption problems within the government, contributed to the construction of inefficient or inappropriate factories, and created serious raw materials and spare parts shortages throughout the economy. Current industrial surveys of Indonesia are filled with references to inactive factories, which either should never have been constructed in the first place or which had been cannibalized for spare parts or simply neglected because of non-availability of foreign exchange. By 1965 the economic fabric of the society had disintegrated, largely because of the inflation, but the direct controls and their consequences had certainly exacerbated the situation. The lessons of Sukarno's direct controls were clear and surely made it easier for the new regime to move away from direct controls. This is not to argue that every society needs or ought to go through the economic wringer that Indonesia experienced between 1964 and 1967 , but it certainly did make it easier for policy makers to adopt different policies.

Fourth, the rapid pace of the inflation itself in 1966 made direct controls and an overvalued exchange rate a patently unworkable policy. With inflation rates of 10 per cent, 20 per cent, or perhaps even 50 per cent per year, policy makers might try to maintain direct controls with a fair amount of success. But with an inflation rate of 400-600 per cent per year, any pegged exchange rate would very quickly become unrealistic, and exports would either cease or enter smuggling channels. Government policy was sure to be frustrated. Some form of floating exchange rate was the only realistic policy in the face of that inflation.

This argument is reinforced by the pre-1966 experience. With direct controls and an accelerating inflation, recorded exports declined significantly in 1962-65 from earlier levels. It is likely that most of this apparent decline was a diversion of exports into smuggling channels. It was common knowledge that substantial amounts of exports were being smuggled. The local wholesale prices of export commodities were sometimes in excess of their export values converted at the legal (unfavorable) exchange rate. ${ }^{20}$ This phenomenon could

19. See Glassburner, "Indonesian Economic," pp. 432-434.

20. K. D, Thomas, "Price Disparity' in Export Trade," Bulletin of Indonesian Economic Studies, No. 4 (June 1966). 
have been due to temporary dips in the international price to which the local price had not yet adjusted, but it was more likely due to the demand of exporters who were smuggling and therefore could afford to pay a high domestic price for the commodities. One estimate has put Indonesian export smuggling at $\$ 140-\$ 200$ million or more per year between 1958 and 1962. ${ }^{21}$ The high figure would have represented a quarter of all exports, a third of non-oil exports. It is likely that these smuggling levels persisted or grew through the middle 1960's.

Fifth, the government had a revenue interest in a floating exchange rate. As noted above, about a third of government revenues come from trade taxes. If the exchange rate were pegged at an overvalued rate and the scarcity premium of foreign exchange were not captured through tariffs or license auctions but instead the licenses were simply handed out, the government would have lost potential revenue. With rapid inflation going on, this revenue loss could quickly become substantial. Further, to the extent that licensing and over-valuation drove exports and imports into smuggling channels, the government would lose revenues. Export and import smuggling flows of $\$ 200$ miliion per year each way could mean a large amount of lost revenue. Government revenues, then, did depend on keeping the effective exchange rates to exporters within a reasonable distance of the free market rate.

There seems to have been, however, some asymmetry with respect to smuggling fears. Though fears of export smuggling were probably influential in keeping the exchange rates realistic and improving the relative returns to exporters, the likelihood of import smuggling did not prevent the government from establishing the import duty structure described in Section II, with duties extending up to 300 per cent. This duty structure has definitely encouarged import smuggling. While export smuggling has virtually ceased because of the narrowing of the gap between FOB prices and exporter receipts, import smuggling continues to be a problem for Indonesia.

\section{Operation of the System}

Some further discussion of the operation of the system is warranted. First, until April 1970 the system operated through dual exchange rates. Multiple exchange rates sometimes carry a connotation as a less "clean" or "respectable" protective device than tariffs or export taxes. This is certainly the impression that one gets from IMF policy efforts. In this light, it is worth stressing that the Indonesian dual exchange rates were simply a way of supplementing the incentives and disincentives of the trade taxes. The Indonesian policy makers found this to be an efficient and reliable way of achieving these effects. The dual exchange rates were essentia11y an extra tax on exports and a subsidy on some imports that were levied and administered by Bank Idonesia. The Bank was considered to be a more reliable agency to enforce these supplementary effects than was the customs agency. Of course, ultimate enforcement

21. C. G. F. Simkin, "Indonesia's Unrecorded Trade," Bulletin of Indonesian Economic Studies, VI, No. 1 (March 1970), p. 32. See also H. V. Richter, "Problems of Assessing Unrecorded Trade," Bulletin of Indonesian Economic Studies, VI, No. 1 (March 1970). 
was still dependent on physical inspection of the exported or imported goods by customs, to make sure that the actual goods corresponded to those for which the foreign exchange had been bought. In one celebrated case in 1968, a group of traders bought foreign exchange at the $B E$ rate and had allies ship empty boxes from Singapore. After suitable payoffs the traders were able to sell most of the exchange at the DP rate for a profit. Still, the Bank did add an extra check on the honesty of the system, and generally it worked. I believe that it is no accident that the dual exchange rate ended in 1970 , only after there was a general feeling within the government that the reliability of the customs service had improved significantly.

A second point worth stressing is the role of access to credit as an important variable in the foreign exchange system. It takes a long time for imports to reach Indonesia. Long distances, irregular shipping schedules, and harbor delays can mean elapsed times from shipment to receipt by the importer of two weeks from Singapore, three weeks from Hong Kong, a month or two from Japan, and three or four months from the U.S. or Western Europe. Somebody has to finance the goods during this period. As part of its general import policy, the Indonesian government prohibited suppliers' credits on "necessity" imports, forcing importers of these goods to pay for the goods at the time that they opened their letter of credit. Also, many importers of nonnecessity goods did not have sufficiently good trade connections abroad to obtain suppliers' credits. With the long delays involved, access to Indonesian credit was important. Though interest rates were substantial in absolute terms and usually positive in real terms after October 1966, demand for credit generally exceeded the supply and informal rationing was necessary. Since much of the financing for trade credit was being provided by the state banks through Bank Indonesia discounting, ${ }^{2}$ the relative availability of trade credit and thus to some extent the demand for imports could be controlled by Bank Indonesia. This provided Bank Indonesia with a great deal of leverage, but it also means that access to credit had some of the characteristics with respect to imports of a licensing system. The "licenses," though, were being allocated by the state banks. Between 1965 and late 1968 these banks had been consolidated in one single institution; after 1968 they were hived off and given a semi-autonomous status.

But the "licensing" system was not really a closed one. There were smaller private banks, which lent funds at 1-2 per cent per month above the rates of the state banks, and there was always Singapore. And, as inflation slowed and inventories of imported goods were again built up, demand for trade credit slackened so that rationing was no longer necessary. By 1970 , some branch managers of state banks were complaining that they could not find enough demanders for their credit. Only for the very low interest loans--e.g., the 1 per cent a month medium term investment credits, which could be used to import capital equipment and were available after mid-1969--was there still significant excess demand. In sum, one could say that the foreign exchange system was not quite as open as it looked, but it was still a good deal more open than most other less developed countries' foreign sector.

22. For a ful1 discussion of the banking system, see David Cole, "New Directions for the Banking System," Bulletin of Indonesian Economic Studies, V, No. 2 (July 1969); John G. Gurley, "Notes on the Indonesian Financial System," paper presented at the Dubrovnik Conferences of the Harvard Development Advisory Service, June 1970 mimeograph; and Arndt, "Banking." 
There is one other interesting aspect to the ban on suppliers credit and the forced use of domestic credit to finance imports. The high domestic interest rates put a premium on fast delivery of goods. It thus worked as a discriminatory tariff, favoring close suppliers. (Or, one could view it as a multiplicative factor on freight rates.) It also favored the use of Singapore as an entrepot for Indonesia, beyond that which the traditional ties of family and finance between the two countries would have warranted. An Indonesian importer who faced 3 per cent a month interest charges would have been willing to pay a Singapore trader up to 10-1/2 per cent more for an American produced item that could be delivered from Singapore in two weeks but would take four months from the U.S. This kind of margin could cover the Singapore trader's warehousing and trans-shipping costs and still leave a margin of profit, since he faced an appreciably lower interest rate. But the higher price paid to the singapore trader meant a foreign exchange loss for Indonesia. If the opportunity cost to Indonesia of borrowing foreign exchange was less than 3 per cent per month, the country would have been better off if the domestic interest rate on loans for imports had been decreased to that opportunity cost rate.

\section{Export Incentives and Export Response}

The import duty structure described in the third section appears to provide positive and substantial effective rates of protection for import substitution activities. By contrast, exports have been operating with negative effective protection. Exports have been subject to explicit export taxes. They have also been implicitly taxed through the operation of dual exchange rates before 1970 and through the over-valuation of the exchange rate caused by import duties. Further, except for investments undertaken through the Foreign and Domestic Investment Programs, exporters have had to pay duties on their imported inputs.

Nevertheless, the relative position of exporters has improved over time. The incentives for exporting compared to other activities in the economy are a compound of three factors: the relative taxation of exporters; the height of the exchange rate; and the general level of domestic prices. ${ }^{3}$ As is seen in columns (1)-(3) of Table 8 , the implicit and explicit taxes on exporters have been reduced considerably. The average effective exchange rate for exporters ${ }^{24}$ has improved from 40 per cent to 90 per cent of the free market exchange rate between early 1966 and the middle of 1971. To the extent that new investors in export activities can get their imported inputs duty free and can get the 1 per cent per month medium term investment credits, effective returns have improved by even more than is indicated by Table 8 .

23. This assumes a constant level of world selling prices for the commodity. If the world price of a particular commodity falls, exports of that commodity will be discouraged. If all export prices fall, one would expect a devaluation to compensate for it.

24. I.e., the actual rupiahs per dollar received by exporters, after allowing for export taxes and multiple exchange rates. 
Table 8

Exporter Exchange Rates: (I) As a Percentage of Free Market

(II) Corrected for Inflation

\begin{tabular}{|c|c|c|c|c|c|c|c|c|c|}
\hline & & \multicolumn{3}{|c|}{$\begin{array}{l}\text { Exporter exchange rates, } \\
\text { as a percentage of free } \\
\text { market rates }\end{array}$} & \multirow{2}{*}{$\begin{array}{l}\text { Free market } \\
(D P) \text { exchange } \\
\text { rate }\end{array}$} & \multirow{2}{*}{$\begin{array}{l}\text { Cost of } \\
\text { Living Index } \\
\text { (Sept.1966=100) }\end{array}$} & \multicolumn{3}{|c|}{$\begin{array}{l}\text { Exporter exchange rates, } \\
\text { corrected for inflation }\end{array}$} \\
\hline & & $\begin{array}{l}\text { "A" } 1 \text { ist } \\
\text { exportsa }\end{array}$ & $\begin{array}{l}\text { "B" list } \\
\text { exportsa }\end{array}$ & $\begin{array}{l}\text { All } \\
\text { exports } b\end{array}$ & & & $\begin{array}{l}\text { "A" list } \\
\text { exportsa }\end{array}$ & $\begin{array}{l}\text { "B" Iist } \\
\text { exportsa }\end{array}$ & $\begin{array}{l}\text { Al1 } \\
\text { exports }\end{array}$ \\
\hline & & (1) & (2) & (3) & (4) & (5) & (6) & (7) & (8) \\
\hline 1966 & $\begin{array}{l}\text { - Feb. } \\
\text { - May } \\
\text { - Nov. }\end{array}$ & $\begin{array}{l}37 \% \\
33 \\
56\end{array}$ & $\begin{array}{l}52 \% \\
70 \\
78\end{array}$ & $\begin{array}{l}40 \% \\
40 \\
60\end{array}$ & $\begin{array}{ll}\text { Rp } & 46.5 / \$ \\
& 97.5 \\
& 95\end{array}$ & $\begin{array}{r}36 \\
51 \\
129\end{array}$ & $\begin{array}{l}47.8 \\
64.1 \\
41.8\end{array}$ & $\begin{array}{r}68.5 \\
135.1 \\
57.8\end{array}$ & $\begin{array}{l}53.6 \\
79.1 \\
44.6\end{array}$ \\
\hline 1967 & $\begin{array}{ll}- & \text { I } \\
- & \text { II } \\
- & \text { II I } \\
- & \text { IV }\end{array}$ & $\begin{array}{l}56 \\
59 \\
69 \\
70\end{array}$ & $\begin{array}{l}76 \\
81 \\
88 \\
91\end{array}$ & $\begin{array}{l}60 \\
63 \\
74 \\
76\end{array}$ & $\begin{array}{l}116 \\
136 \\
158 \\
187\end{array}$ & $\begin{array}{l}166 \\
183 \\
205 \\
269\end{array}$ & $\begin{array}{l}39.1 \\
44.0 \\
54.5 \\
48.4\end{array}$ & $\begin{array}{l}53.3 \\
60.0 \\
69.9 \\
63.4\end{array}$ & $\begin{array}{l}41.8 \\
47.1 \\
58.1 \\
52.9\end{array}$ \\
\hline 1968 & $\begin{array}{ll}- & \text { I } \\
- & \text { II } \\
- & \text { II I } \\
- & \text { IV }\end{array}$ & $\begin{array}{l}72 \\
68 \\
64 \\
69\end{array}$ & $\begin{array}{l}92 \\
88 \\
86 \\
84\end{array}$ & $\begin{array}{l}77 \\
74 \\
70 \\
73\end{array}$ & $\begin{array}{l}289 \\
338 \\
388 \\
437\end{array}$ & $\begin{array}{l}424 \\
439 \\
487 \\
502\end{array}$ & $\begin{array}{l}49.1 \\
52.2 \\
51.3 \\
59.7\end{array}$ & $\begin{array}{l}62.5 \\
67.8 \\
68.7 \\
72.7\end{array}$ & $\begin{array}{l}52.8 \\
56.8 \\
55.7 \\
63.7\end{array}$ \\
\hline 1969 & $\begin{array}{ll}- & \text { I } \\
- & \text { II } \\
- & \text { III } \\
- & \text { IV }\end{array}$ & $\begin{array}{l}76 \\
78 \\
78 \\
79\end{array}$ & $\begin{array}{l}86 \\
88 \\
88 \\
88\end{array}$ & $\begin{array}{l}78 \\
80 \\
80 \\
81\end{array}$ & $\begin{array}{l}396 \\
380 \\
378 \\
378\end{array}$ & $\begin{array}{l}544 \\
537 \\
541 \\
566\end{array}$ & $\begin{array}{l}55.3 \\
55.3 \\
54.6 \\
52.9\end{array}$ & $\begin{array}{l}62.7 \\
62.4 \\
61.6 \\
58.9\end{array}$ & $\begin{array}{l}56.9 \\
56.7 \\
56.0 \\
54.2\end{array}$ \\
\hline 1970 & $\begin{array}{ll}- & \text { I } \\
- & \text { II } \\
- & \text { II I } \\
- & \text { IV }\end{array}$ & $\begin{array}{l}79 \\
90 \\
90 \\
90\end{array}$ & $\begin{array}{l}88 \\
90 \\
90 \\
90\end{array}$ & $\begin{array}{l}81 \\
90 \\
90 \\
90\end{array}$ & $\begin{array}{l}378 \\
378 \\
378 \\
378\end{array}$ & $\begin{array}{l}616 \\
607 \\
608 \\
616\end{array}$ & $\begin{array}{l}48.6 \\
56.1 \\
56.0 \\
55.3\end{array}$ & $\begin{array}{l}54.1 \\
56.1 \\
56.0 \\
55.3\end{array}$ & $\begin{array}{l}49.8 \\
56.1 \\
56.0 \\
55.3\end{array}$ \\
\hline
\end{tabular}


Table 8 (cont)

Exporter Exchange Rates: (I) As a Percentage of Free Market

(II) Corrected for Inflation

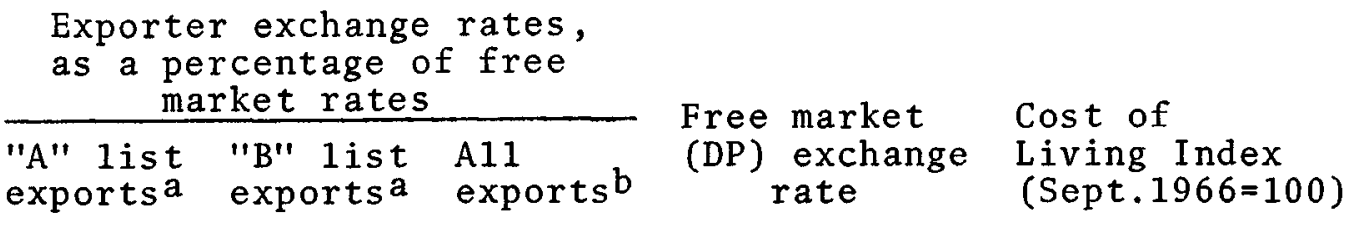

(1)

(2)

(3)

(4)

378

378

90
90

- II

- III

90

(end)

$\begin{array}{ll}90 & 90 \\ 90 & 90 \\ 90 & 90\end{array}$

415
Exporter exchange rates, corrected for inflation

$\begin{array}{lll}\text { "A" 1ist "B" list } & \text { A11 } \\ \text { exportsa } & \text { exportsa exports }\end{array}$

(6)

51.9

63.3

51.9

53.3

60.2

51.9

$53.3 \quad 53.3$

$621 \quad 60.2 \quad 60.2 \quad 60.2$

a. The "A" list was composed of rubber, copra, coffee, tobacco, palm oil, palm kerne1s, pepper, and tin. Before July 1967, tea, sisal, and sugar were also in this group. The "B" 1 ist was composed of virtually al1 other exports, except petroleum, which was subject to its own regime. A very small quantity of handicrafts and manufacturers had higher effective exchange rates before July 1967 and have been exempted from the 10 per cent export tax since April 1970.

b. Excluding petroleum.

Source: Bruce Glassburner, "Pricing of Foreign Exchange in Indonesia, 1966-67," Economic Development and Cultural Change, XVIII, No. 2 (January 1970); and Bank Indonesia figures. 
To get the real returns to exporting, though, we must multiply the figures in columns (1)-(3) by the free market exchange rate to get the rupiahs received per dollar of export, and then correct these for the price level. The results of these calculations are shown in columns (6)-(8). The amount of real improvement, in the rupiah receipts depends on which period is used as the base. Between February 1966 and the third quarter of 1971 , the real rupiah receipts of a11 exporters improved by only 12 per cent. The reason, of course, is that the cost of living index increased by 17.2 times during this period, while the free market exchange rate increased by only 8.9 times. A major reason for the exchange rate not increasing by as much as the cost of living index was the large inflow of foreign aid after 1966. This allowed an increased demand for imports to be satisfied without the need for devaluing the exchange rate by as much as would otherwise have been the case. Most of the relative adjustment between the cost of living index and the exchange rate, however, had taken place by the first quarter of 1967. Between 1967-I and 1971-III, the cost of living index rose 3.7 times and the exchange rate rose 3.6 times. Accordingly, the 50 per cent improvement in the relative taxation of exports between these dates was mirrored by a just under 50 per cent improvement in the real rupiah receipts of exporters.

The returns to exporters have not been uniform, however. Before April 1970, the opportunities for discrimination among exports were large. Explicit export taxes were 10 per cent on some commodities and 25 per cent (later 15 per cent) on others. Further, the dual exchange rate, check-prices, ${ }^{25}$ and the levying of the export tax on the checkprice rather than the actual export price offered room for greater discrimination. In theory the check-price could range between 0 per cent and 100 per cent of the FOB export price. The former meant that the exporter paid no export tax and converted all of his foreign exchange at the higher $D P$ exchange rate; the latter meant a 10 , 15, or 25 per cent tax on the full FOB value, with the remainder of the exporter's foreign exchange converted at the less favorable BE rate. With the 25 per cent export tax and a 16 per cent exchange rate margin between the $\mathrm{BE}$ and the $\mathrm{DP}$ exchange rates, the potential differential returns were substantial.

The differential returns to exports in the $A$ and $B$ categories are indicated in Table 8 . These differential returns had two justifications. The A list exports were the traditional exports which had well-established markets. The B list items were considered newer and more in need of explicit or implicit incentives to help them break into new markets. Also, the lower check-prices for B list exports were as much a matter of necessity as desire by the Ministry of Trade. World export prices were less readily available for most B list items than for A list items. The Ministry's information gathering facilities were not sufficiently developed to allow it to set check-prices for B list exports. Consequently, the check prices were set by exporter associations. After mid-1967, these associations tended to set their check

25. Check $\rightarrow$ prices were the nominal prices at which exporters were required to sell their foreign exchange receipts to the government (at the unfavorable BE exchange rate). Since these check-prices were frequently set below the true FOB export price, the exporter could keep the difference between the FOB price and the checkprice and sell it for rupiahs at the more favorable DP exchange rate. 
prices at roughly 50 per cent of FOB value. This seems to have been a rough compromise between the associations' desires to have a zero check-price and the Ministry's desire to have high check-prices for export tax revenue purposes.

Within the A list there were differences in exporter returns among commodities and over time. The government's goals included obtaining revenue from export taxes and ensuring adequate exporter returns so as to discourage smuggling. Also, short-run supply elasticities were assumed to be quite low, so that the "non-functional" returns from temporary high prices could be taxed away without serious consequences. Depending on the time and the crop, one of these goals would dominate. Unexpected changes in actual export prices after the check-prices for the month had been announced were an additional element in the determination of actual exporter returns. Table 9 shows the quarterly returns to exporters on A list exports in 1968 and 1969. Rubber and copra were consistently favored over the other commodities. There were widespread fears that substantial amounts of copra and rubber were being or would be smuggled if sufficient returns were not forthcoming. Also, the Ministry was concerned about the deterioration of the stock of rubber and coconut trees and wanted to offer some encouragement for better upkeep and replanting. By contrast, coffee was in surplus in Indonesia, and, as a member of the International Coffee Agreement, Indonesia was 1imited as to coffee exports. There was no need to encourage more coffee production. Palm oil, palm kerne1s, and pepper all had favorable prices and good markets. They did not seem to need extra incentives.

Table 9

Effective Exchange Rates, Major Export Commodities, 1968-1969 (Rupiahs per dollar)

\begin{tabular}{|c|c|c|c|c|c|c|c|c|}
\hline & \multicolumn{4}{|c|}{1968} & \multicolumn{4}{|c|}{1969} \\
\hline & I & I I & I I I & IV & I & I I & I I I & IV \\
\hline $\begin{array}{l}\text { Rubber } \\
\text { Copra } \\
\text { Coffee } \\
\text { Palm Oil } \\
\text { Palm Kernels } \\
\text { Pepper }\end{array}$ & $\begin{array}{l}206 \\
213 \\
206 \\
212 \\
210 \\
211\end{array}$ & $\begin{array}{l}234 \\
236 \\
224 \\
228 \\
226 \\
240\end{array}$ & $\begin{array}{l}271 \\
255 \\
242 \\
242 \\
242 \\
244\end{array}$ & $\begin{array}{l}325 \\
307 \\
283 \\
285 \\
277 \\
284\end{array}$ & $\begin{array}{l}314 \\
308 \\
278 \\
283 \\
291 \\
277\end{array}$ & $\begin{array}{l}314 \\
304 \\
277 \\
281 \\
282 \\
279\end{array}$ & $\begin{array}{l}317 \\
311 \\
285 \\
289 \\
280 \\
297\end{array}$ & $\begin{array}{l}301 \\
316 \\
293 \\
289 \\
282 \\
280\end{array}$ \\
\hline
\end{tabular}

Source: C. G. F. Simkin, "Indonesia's Unrecorded Trade," Bulletin of Indonesian Economic Studies, IV, No. 1 (March 1970); and Ministry of Trade figures.

Since the April 1970 consolidation of the exchange rate, there has not been very much discrimination among exports as to effective returns. Oil exports have their own regime, and the tiny category of manufactured exports are exempt from the 10 per cent export tax, but the remainder are all subject to the 10 per cent export tax. The tax is appiied to "guideline" prices set by the Ministry of Trade, 
but in most cases these guideline prices have been set very close to actual export prices. Only in a few instances has the Ministry deliberately manipulated these prices: In 1970, the guideline prices of timber were set low, so as to give an extra incentive to timber extraction. And guideline prices that are slightly above actual prices have been set for very low grades of rubber, so as to discourage low grade rubber exports. But the effects have not been very great. Also, new investors can qualify for exemptions on imports and may qualify for the 1 per cent medium term credits. But these are open to investors in virtually all export areas, so discrimination among exports does not enter here.

Just as for import tariffs, though, the nominal export tax does not tell the whole story. We should be looking at the value added in export activities and analyzing by how much value added is depressed by the export tax. If different export activities had substantially different percentages of domestic value added, the uniform 10 per cent export tax could be yielding large differences in effective taxation and could have strong allocative effects. This would be particularly important for manufactured exports. But this is less important for Indonesia's current exports, which are entirely minerals and agricultural raw materials. Domestic value added bulks very large in all of these activities, so the 10 per cent export tax is very close to a uniform 10 per cent tax on value added. Even in cases in which processing of exports is possible--e.g., crumb rubber, coconut oil from copra, refining of mineral ores--the primary input is the basic raw material which also carries a 10 per cent export tax. Accordingly, the effective tax on the value added in the processing is still 10 per cent.

The response of exports to the improvement in returns over time and to the differential returns to different commodities is difficult to measure. The dollar value of total exports has grown from $\$ 714$ million in 1966 to $\$ 1,173$ in 1970 . The sub-total for exports other than petroleum has grown from $\$ 499$ million to $\$ 739$ million over the same period. But it is difficult to determine how much of this latter growth is true growth and how much is simply a return of exports to official channels from smuggling. When we look at individual commodities, the same question of real growth as against smuggling diversion arises. Some apparent growth in volumes may simply be better reporting by the statistical agencies. Further, the full supply response for tree and bush crops like rubber, coconuts (copra), palm oil and kernels, coffee, and pepper surely takes longer than the five years under study. Some short run response to improved returns is possible from more intensive picking and tapping and from inventory changes, ${ }^{26}$ but the full response from new plantings takes longer. Years of neglect under Sukarno cannot be undone quickly. Finally, exporters respond not only to rupiah receipts per dollar but also to international selling prices. Very favorable international prices can offset poor rupiah returns (this is usually the justification offered for heavy taxation of exports) and conversely.

The recorded volumes of Indonesia's major exports (excluding petroleum) over the past decade are offered in $\mathrm{Table} 10$. Rubber and copra exports do seem to have improved during the past three years compared to the previous eight. This may be true growth; it may be a diversion from smuggling; it is probably an analgam of the two. But

26. Though, at the rates of interest prevalent in the Indonesian economy, large inventories are not likely. 
even if it only represents a diversion from smuggling, the recorded increase does indicate that exporters are at least sensitive enough to official rupiah returns to change their channels of export. The trends in the other commodities are less observable. The year 1970 does seem to have been a good year for palm oil, palm kerne1s, tin, and tobacco, but it is too early to tell if these performances are going to be typica1. Coffee exports are limited by the International Coffee Agreement. And pepper exports in 1970 were hampered by a serious pepper vine disease.

$\mathrm{Tab} 1 \mathrm{e} 10$

Exports of Major Commodities, 1960-1970

(Volume in thousands of metric tons)

\begin{tabular}{|c|c|c|c|c|c|c|c|c|c|c|c|}
\hline & 1960 & 1961 & 1962 & 1963 & 1964 & 1965 & 1966 & 1967 & 1968 & 1969 & 1970 \\
\hline Rubber & 556 & 657 & 777 & 581 & 627 & 708 & 680 & 652 & 771 & 755 & 825 \\
\hline Copra & 168 & 247 & 110 & 108 & 150 & 124 & 119 & 114 & 217 & 157 & 188 \\
\hline Coffee & 41 & 66 & 57 & 71 & 59 & 108 & 98 & 133 & 85 & 104 & 108 \\
\hline Palm Oil & 106 & 117 & 100 & 110 & 133 & 126 & 177 & 133 & 152 & 120 & 173 \\
\hline Palm & $\mathrm{n} \cdot \mathrm{a}$ & 33 & 31 & 31 & 33 & 33 & 32 & 39 & 37 & 28 & 44 \\
\hline Pepper & 12 & 18 & 11 & 28 & 22 & 12 & 21 & 37 & 25 & 13 & 2 \\
\hline $\mathrm{T}$ in & 35 & 24 & 28 & 21 & 0.5 & 19 & 12 & 21 & 32 & 27 & 35 \\
\hline Tobacco & 3 & 3 & 11 & 10 & 2 & 14 & 13 & 10 & 9 & 6 & 17 \\
\hline
\end{tabular}

Perhaps the best indicator of the response to improved returns to exports has been the growth of timber exports. In 1966, annual timber exports were under $\$ 10$ million. In 1970 , they were roughtly $\$ 125$ million, and in the first quarter of 1971 they were over $\$ 40$ million. It is difficult to believe that increases of this magnitude could have occurred in the absence of the general freeing up of the foreign exchange system that has simultaneously occurred.

Despite the continuing explicit and implicit taxation of exports, the actual and potential comparative advantage of Indonesia in mineral, timber, and some agricultural exports has been so great that substantial amounts of new investments have been made or are intended for these areas. Another way of expressing this is that the opportunity costs in the absence of exports on the natural resources in these areas are so low that even in the face of tax disincentives these activities are quite profitable and have warranted substantial new investment. Of the $\$ 1,605 \mathrm{million}$ in foreign investment (excluding oil related investment) approved by the Foreign Investment Board through September $1971, \$ 1,032$ mil1ion was intended for agriculture, forestry, fishing, mining, and quarrying. 
Still, the negative protection given to exports has had its allocative effects. It has effectively ruled out substantial exports of Indonesian manufactures. The incentives are simply not there. Only one firm has successfully navigated the oceans of bureaucratic red tape and has established a duty free zone for itself, importing transistor components from Hong Kong, assembling them, and exporting the finished transistors back to Hong Kong. A handful of batiks and handicrafts are the only other manufactured products that leave Indonesia. The government has established a bonded warehouse, which it eventually hopes to expand into a duty-free manufacturing zone, but progress has been slow. The negative protection has also surely discouraged investments at the margin in export activities, though this has been partially mitigated by the foreign and domestic investment programs, which allow import duty exemptions (but not an export tax exemption) for exporting activities as well as import substitution activities.

\section{Pricing and Moving Tied Foreign Aid}

Tied foreign aid has presented a unique problem for Indonesia's open exchange rate system. Tied aid is worth less to the user than an equal amount of cash foreign currency, since the tied aid usually has to be used to buy goods that are overpriced in world markets. For most LDC exchange rate regimes this does not present a problem. Since their exchange rates are over-valued and subject to licensing, the licenses have a scarcity value that is higher than the nominal value of the foreign exchange. As long as the scarcity premium of the license is greater than the excess cost of the goods that are tied to the aid, aid foreign exchange can be sold without any extra effort. Importers would prefer to get a license for imports that are untied, but they can still make a profit from the license for tied imports.

But if foreign exchange does not have a scarcity premium above its face value, tied foreign aid cannot be sold alongside cash foreign exchange. Some means of pricing it lower than cash foreign exchange must be found. Further, the tied aid from different countries will have different equilibrium prices depending on the degree of excess cost over world prices that is involved in the tied goods. ${ }^{7} \mathrm{~A}$ single exchange rate for all tied foreign aid will either fail to move some of the more over-priced aid goods or will offer a windfall gain to the buyers of the less over-priced aid goods and thus yield less counterpart revenues for the government.

The obvious solution is to auction the aid from each donor separately and let the market determine the price for each aid tranche. Unfortunately, the donors of the more over-priced aid are reluctant to see their aid sold at a rate that is "too cheap," and the IMF has frowned on anything that smacked of multiple exchange rates.

Faced with this dilemma, Indonesia has tried a number of policies. From early 1967 through mid-1968, all aid was priced uniformly at a rate that was 10-20 per cent below the primary (BE) exchange rate, with occasional help from favorable credit terms. Japanese aid funds moved very rapidly; American aid funds moved more slowly. In July

27. See Glassburner, "Pricing," pp. 180-183. 
1968 the aid exchange rate was unified with the BE rate, and special credit terms were employed to give aid funds an advantage. Differential credit terms among countries allowed some adjustment for the different sources of aid. It is not clear why this arrangement was considered unsatisfactory, but when the exchange rate was consolidated in April 1970, Indonesia reverted to the former practice of a single explicit price for aid that was 14 per cent below the cash foreign exchange rate. Again, Japanese aid moved very fast. In December, the aid rate was consolidated with the official exchange rate, and differential credit terms were again used. Finally, after the devaluation of August 1971, Indonesia won from the donors the agreement that explicit differential rupiah subsidies could be given to the buyers of different countries aid funds. Thus all buyers of aid funds will have to pay the official rate, $R p 415=\$ 1$ for their funds, but the buyers of the more over-priced aid will get back a larger rupiah "refund" than will the buyers of the less over-priced aid funds. With a little practice, the Indonesian authorities ought to be able to duplicate roughly the results of an auction system.

Foreign Investment

Foreign investment poses a difficult political and economic problem for Indonesia. The welcoming of foreign investment has been one of the hallmarks of the economic policies of the new regime. The government has already approved over $\$ 1.6$ billion in foreign investment in four years. This sum, if effected, will leave a significant mark on the Indonesian economy. In addition, foreign oil companies have spent an estimated \$350-400 million on oil exploration and field development.

Foreign investment brings capital and skills to the Indonesian economy. But it also brings foreign claims on the economy. It gives foreigners a significant "say" in the Indonesian economy. Foreigners may out-compete and drive to the wall Indonesian entrepreneurs; consumers may benefit but entrepreneurs suffer. Foreign investment can mean a net foreign exchange loss if the foreigners' activities are given excessive protection. Mineral extraction and forestry by foreigners may pose special political problems for the future. Future generations of Indonesians may forget or discount the taxes paid and employment created by the foreigners and simply ask, who has "plundered" Indonesia's natural resources and why?

In its eagerness to establish a good name with foreign investors and partly from a lack of technical expertise in dealing with foreign investors, the Indonesian Government was probably too lenient in its tax concessions in the early contracts, particularly in the mining and forestry areas. Replanting provisions in forestry contracts have been absent or weakly enforced. More recent contracts have been noticeably tougher. But still, one can question the value of tax holidays and tariff duty exemptions. Most of the home countries of the foreign investors have double taxation provisions, whereby income taxes paid in Indonesia are an offset against taxes in the home country. Thus, an income tax holiday for the foreign investor mostly benefits the home country treasury, not the foreign investor. Why, then, are the foreign investors eager to obtain a tax holiday? In some cases, the tax holiday does mean a net gain for the foreign investor. But, primarily, the tax holiday appears to be interpreted as an indication of good faith on the part of the host government. The government ought 
to be able to devise a less costly token of good faith. The tariff duty exemptions lose revenue and have the expected allocative effect: they encourage capital-intensive production processes using imported capital equipment.

The tax concessions to foreigners have had further costs, since the provisions are applicable to approved domestic investors. The Foreign Investment Law, enacted in early 1967, raised the demand that equal treatment be given to domestic investors. Accordingly, in November 1968 the Domestic Investment Law came into force, with comparable provisions.

In some areas, the government has had second thoughts about foreign investment. Beginning in mid-1968, the Ministry of Industries began closing some manufacturing areas to foreign investors. By December 1970 this list had reached forty-one industries. These industries are listed in Table 11. In practice, a few exceptions have been made, and if a foreign investor is persistent enough he may be able to win his case, particularly if he is willing to invest outside of Java. Nevertheless, the clear intent of the action is to protect the existing producers in these industries from future competition by new foreign entrants. To the extent that domestic entrepreneurs by themselves are not prepared to enter some of these industries, either because of capital or technological barriers, these industries are effectively protected from further competition.

Some features of Table 11 are worth noting. First, canned milk, dry cell batteries, galvanized sheets, and mosquito incense are also on the list of banned imports. With imports banned and foreign entry foreclosed, the present producers face actual and potential competition only from domestic entrants and smuggled imports. Further, in the areas of cigarettes, dairy products, detergents, shoe polish, and beverages, the primary beneficiaries of this barrier to new entry are earlier foreign investors. Foreign investors will also benefit from the entry barriers on dry cell batteries, sewing machine assembly, leather shoes, porcelain tiles, and bicycle tires and tubes. In these areas, the foreign investment barriers may yield the worst of all possible worlds: highly protected markets, large profits for foreigners, and thus large claims by foreigners on the Indonesian economy. Future entry, or at least the potential for entry, would clearly be in the interests of everyone (except the current producers). A1so, the areas of wigs, leather tanning, and watch assembly are actual and potential export industries. There seems to be little gain to Indonesia to preventing foreign entry into these areas.

This entry foreclosure brings out the essential sensitivity problem of foreign investment. Domestic entrepreneurs and even earlier foreign entrepreneurs are unhappy about facing new competition. This has not yet become a problem in mining and mineral exploration, because Indonesians clearly do not yet have the large capital sums and technological skills that are necessary (though Indonesia has developed a domestic capability in petroleum). Over 30 per cent of foreign investment has been intended for mining activities; only 1 per cent of domestic investment has been similarly intended. As Indonesian capabilities in mining are developed in the future, the sensitivity to foreign investment in mining will surely increase.

There is no easy way out of this dilemma. Outright foreclosure of new foreign entry may generate greater costs than benefits. Rather, 
Table 11

Industries closed to Foreign Investment, as of December 1970

Milk and other dairy products

Dry ce11 batteries

Monosodium glutamate

Cigarettes

Matches

Paint, varnish, lacquer

Plastic and leather shoes

Agricultural tools

Nai1s, screws, nuts, bolts

Laundry soaps

Detergent

Coconut oil

Nail-wire drawing

Flour mills

Tooth paste

Biscuits, bread, confectionery

Bicycle tires and tubes

Boot polish

Plastic ware

Printing

Bicycle assembly

Printing ink

Ename lware

Aluminum house-hold ware

Candy

Soft-drinks

Concrete and porcelain tiles

Bricks and tiles

Sewing machine assemb1y

Ice making

Can making

Tooth brushes

Mosquito incense

Watch assembly

Corrugated cardboard

Instant noodles

Zip fastener

Tanning

Hair wigs

Galvanized iron sheet

Fabric manufacturing except integrated spinning and weaving

Source: Ministry of Industries; and Wilhe1m Boucherie, "Some Preliminary Estimates Concerning the Present Structure of Industry" (Djakarta: Harvard Development Advisory Service, 1971), mimeograph.

excessively protected market positions should not be given to foreign investors, or to domestic investors either, and the tax concessions to foreigners should be withdrawn or shortened. This is especially true for mineral and forestry concessions. If foreign investors still find it profitable to enter areas in which domestic entrepreneurs have an "infant industry" argument for survival, the presently available 
low interest rate medium-term investment credit program is the suitable instrument for assistance.

\section{A Strategy for the Future}

With the stabilization program now a success, the attention of Indonesian policy-makers will be turning increasingly toward devising a long-run development policy. The second five year plan (1974-1979) will be based on that policy. While agriculture will remain the most important sector, more attention must and will be given to an industrialization strategy. The foreign trade sector will surely enter crucially into that strategy.

Indonesia must develop a coherent and enforceable tariff structure. That structure must be aimed at promoting labor-intensive manufactures for both domestic consumption and export. The pitfalls of an industrialization strategy based solely on import substitution, à 1 a Pakistan, India, and Latin America, are now readily apparent: inefficient industries develop which refuse to disappear or become efficient; the small economic size of markets precludes efficient production in some areas; import licensing spawns a bureaucratic morass; efforts at exporting manufactures require extra subsidies which may turn out to be uneconomic; industrial expansion into intermediate and capital goods becomes difficult as the producers of final goods become used to access to foreign supplies at favorable implicit exchange rates; the industrial structure becomes excessively capital intensive; income distribution takes an unwelcome swing toward the new industrialists. ${ }^{28}$

An industrialization strategy more keyed to exports should avoid most of these pitfalls. Also, Indonesia is relatively well located to take advantage of future efforts by Japan to farm out its 1 aborintensive manufactures. As wage rates rise in Korea, Taiwan, Hong Kong, and Singapore, the Indonesian economy could be in a good position to become a manufacturing supplier for Japan.

This kind of strategy would argue for a tariff structure with a few broad categories of relatively low rates. Excessive effective protection would not be given to domestic producers. Duties on capital goods would be positive rather than zero, so as to give actual or potential domestic capital goods producers some modest effective protection and to discourage capital-intensive manufacturing generally. The low tariff structure would mean that the exchange rate would continue to bear the brunt of adjusting Indonesia's foreign trade sector to changes in the external and internal environment. Exports would thus not be subject to very much implicit taxation from an overvalued exchange rate. As the general taxation efforts by the Government improve, the Government will have less need to rely on trade taxes. It is even quite possible that this tariff structure

28. For a complete discussion of these issues, see I.M.D. Little, Scitovsky, Tibor, and Maurice Scott, Industry and Trade In Some Developing Countries (New York: Oxford University Press, 1970). 
would increase revenues, since the low rates would encourage the return of smuggling flows to legal channels and the imposition of duties on capital goods, other exempt items, and on new investors 'would generate increased revenues. A general excise tax at a high rate (perhaps 100 per cent) would be retained for luxuries.

This kind of strategy would continue to encourage Indonesia's traditional raw material exports, while stimulating new manufactured exports. But even with moderate duties on imputs, manufacturers aiming at export markets would still be at a disadvantage if they had to use imported or protected inputs. Establishing a duty-free zone or giving rebates on the tariffs paid on imported inputs is one solution. As a short-run measure, this will probably be the fastest and easiest way of entering the labor intensive areas of assembling manufactured components for export markets. But as a long-run solution it is not entirely satisfactory. It leads to a preference for imported inputs over domestically produced inputs, since the latter are presumably priced so as to take advantage of the tariff protection and also may be using imported inputs on which no rebate is available. The only satisfactory scheme would be one in which the exporter received the tariff rebate on his inputs, regardless of their source.

Maintaining an outward-directed industrialization strategy will not be easy. There will always be a strong temptation to aim exclusively for the secure, protectable domestic market. The voices of protectionism are likely to grow stronger, not weaker, as Indonesia's manufacturing sector expands in the short-run. The current banned import list could be a taste of what might happen in the future. But the long-run costs of an inward-looking, protectionist strategy are clearly very high. I believe that Indonesia can and should avoid them. 